\title{
ERKEN CUMHURIYET DÖNEMINDE KENTLILEŞME VE ŞEREF AKDIK RESIMLERINDEKI YANSIMASI
}

\author{
URBANIZATION IN THE EARLY REPUBLICAN ERA AND ITS REFLECTION ON \\ ŞEREF AKDIK'S PAINTINGS
}

ilkay Canan Okkalı*, ìlona Baytar**

Öz

Türkiye'de Cumhuriyetin ilanı ile siyasi ve toplumsal yapıda görülen değişimler, devlet tarafından belirlenen modernleşme çizgisinde gelişir. Özellikle kentlileşme ve kentsel yaşamın getirdiği yaşam pratikleri, 20. yüzyıl Türkiye'sini gelenekselden farklı bir yere taşır. İçinde geliştiği toplumun dinamikleriyle şekillenecek olan Cumhuriyet Dönemi Türkiye'si için inkılâplar çok önemlidir. Devletçilik altında gerçekleşecek olan inkılâplar, salt siyasi yapıyla sınırlı kalmayacak ulusal bilincin altında kültürel milliyetçiliği de geliştirecektir. Öyle ki tek partili dönemde devlet destekli Halkevleri açılacak, sanatçılar Anadolu'ya gönderilerek, kırsal bölge yaşayanı da yeni sanat ortamıyla tanışmıs olacaktır. Erken Cumhuriyet Dönemi sanatçıları arasında yer alan Şeref Akdik de İnkılâpçı ressamlardan biridir. Kentlileşme çizgisinde gelişen modern hayatı, yeni yaşam mekânlarını, yeni imgesiyle Türk kadınını, gelişen sanayi kollarını ve işçi sınıfını betimler.

Bu çalışmada ressam Şeref Akdik'in 1930'lardan 1960'lara uzanan süreçteki resimleri bağlamında erken Cumhuriyet Dönemi'nin kentlileşme olgusu, yeni çalışma mekânları ile bu mekânların kullanıcıları ve değişen yaşamlarındaki kesitler üzerinden ele alınmıştır.

Anahtar Kelimeler: Şeref Akdik, Kentlilik Resimleri, Kentlileşme Olgusu, Sanayileşme Resimleri.

\section{Abstract}

After the declaration of the Republic, changes in the political and social structure advances in the direction of the course of modernisation determined by the state. The lifestyles brought about particularly by urbanisation and urban life carries the $20^{\text {th }}$ century Turkey towards a non-traditional place. Reforms are fundamental for the Republican-period Turkey, which will be shaped by the dynamics of the society where it flourishes. The reforms that will materialise under etatism will not only be limited to the political structure but will also reinforce cultural nationalism under the national conscience. So much so that Community Houses sponsored by the state will be established during the single-party period and artists will be sent to Anatolia, to acquaint the residents of rural areas with the new ways of art. Şeref Akdik, an artist of the early Republican period, is one of the Revolutionary painters. He depicts the modern life flourishing in the course of urbanisation, new living spaces, Turkish woman with her new image, developing areas of industry and working class.

This study discusses the urbanisation phenomenon of the early republican period, in terms of new workspaces and the users of these workspaces, as well as a slice of their changing lives, within the context of the paintings of the artist Şeref Akdik, from the 1930s to the 1960s.

Keywords: Şeref Akdik, Urbanism Paintings, Urbanisation Phenomenon, Industrialisation Paintings.

Araştırma Makalesi // Başvuru tarihi: 12.03.2020 - Kabul tarihi: 06.06.2020.

*Dr. Öğr. Üyesi, Trabzon Üniversitesi, Güzel Sanatlar Fakültesi, Resim Bölümü, icanikli@gmail.com, https:// orcid.org/ 0000-0003-1817-4060.

**Dr., Araştırmacı, TBMM Genel Sekreterliği, ilonabaytar@gmail.com, https://orcid.org/ 0000-0001-8564-5665. 


\section{Giriş}

18. yüzyılda Osmanlı Devleti ile başlayan modernleşme olgusu, Cumhuriyetin ilanı sonrası hız kazanarak devletin birincil projeleri arasında yer alır. Etkin olarak nasıl işleyeceğinin devlet tarafından belirlendiği modernleşme, aslında kamusal mekânlarda ve toplumsal düzende de dönüşümleri gerekli kılar. Dolayısıyla Erken Cumhuriyet Dönemi'nde çok sayıda yeni kamusal mekânlar oluşmaya başlayacak, kadınların kamusal yaşama katılımı önemle vurgulanacak ve aynı zamanda da Batı modernleşmesinde önemli bir yer edinen ve bizde henüz oluşmamış olan burjuva ve işçi sınıfının varlığı üzerinde önemle durulacaktır. Yeni modern devletin toplumsal yapıda ürettiği aslında, modernist bir kent planlama pratiği olsa gerektir ki bunu Cumhuriyet Türkiye'si ancak 1930'lu yıllarda hayata geçirmeye başlar. Geleneksel biçimi büyük ölçüde tasfiye ederek başlayan yeni ölçekli modernist kent planlaması, toplum yapısının getirdiği intiyaçlar doğrultusunda yeni kamusal alanları da beraberinde getirecektir. Kuşkusuz modern kentlerin vazgeçilmezi bulvarlar, meydanlar ve bunların etrafında kurgulanan kamu yapılardır. Kent imgesinin oluşturulduğu bu dönemde yapılandırılan ulaşım ağı, sanayileşme ile birlikte kurulan fabrikalar ve fabrika çalışanlarının nefes alacağı parklar yeni oluşan mekânlardaki modern kentliliğin göstergeleri arasında yer alırken, fabrika çalışanları da kent yaşamının yeni toplumsal sınıfı olarak yer almaya başlar. Yavaş yavaş eskinin tasfiye edilmesi ile görünürlük kazanan yeni kentsel düzen ve içinde geliştiği toplumsal yapı, sanat eserlerine de yansır ve çağının tanığı olan sanatçıların içinde yaşadığı toplumu, o toplumun sorunlarını, değişimlerini yansıttığı birer belge niteliğine dönüşür.

$\mathrm{Bu}$ araştırma betimsel modele dayalı nitel bir araştırmadır. Araştırmada literatür taraması yapılmış ve veri toplanmıştır. Temel nitelikli sanat tarihi kitapları ve konuyla ilgili makale ve tezler incelenmiştir. 1930'lardan 1960'lara uzanan süreçte Türkiye'deki sanayileşme ve gelişim çizgisi içerisinde Şeref Akdik'in sanatsal gelişimi, sanayi, teknolojik gelişimler, eğitim reformlarının vurgusu ile kentli ve çalışan insanların betimleri üzerinden incelenmiştir. 
SDÜ ART-E

Güzel Sanatlar Fakültesi Sanat Dergisi

Haziran'20 Cilt:13 Sayı:25

ISSN 1308-2698

\section{Erken Cumhuriyet Yıllarında Sanayileşme ve Kentsel Planlama}

1923 yılında Cumhuriyet kurulduğunda değişen sadece devletin yönetim sistemi değildir, aynı zamanda toplumsal yapıda da değişimler söz konusudur. Eskiler tasfiye edilerek yerini yeni olana bırakırken Yeni Türkiye Cumhuriyeti'nin başkenti de değişmiştir, artık yeni başkent Ankara'dır. Dönemin resmî ve popüler yayınlarında buradan "ulusun kalbi" olarak bahsedilecektir (Bozdoğan'dan akt. Okkalı, 2017:359). Modernleşme ve nasıl işleyeceği de devlet tarafından belirlenecektir. Modernist kent planlama pratiği en temel yapılanmalar içinde yer alırken, aynı zamanda kent dışı yaşam alanlarının da ilerlemesine ilişkin ulaşım ve peyzaj çalışmaları önem kazanır (Arıtan, 2008:49-56). Klasik Osmanlı’nın yapılanmasında görülen çarşı, cami, hamam üçlemesi yeni kentsel oluşumda bulvar, meydan, kamu yapıları ile yer değiştirmeye başlar (Bozdoğan, 2008:83). Yeni kentsel oluşumlar hızla uygulanmaya girişilir ve ilk örnekleme modeli, başkent Ankara'da görülür. Aslında sınırlı da olsa Osmanlı'dan devralınan kentsel planlama 1930'lu yıllarda hız kazanmaya başlayacaktır (Tekeli, 1998:3).

Kentsel planlamanın ve rasyonel yaşam biçiminin pratikleri arasında ulaşım ağları ve kamusal mekânın yeni ortaya çıkardığı parklar yer alır. Özellikle demiryolları, 1930'ların Türkiye'sinde önemli bir yere sahiptir. Öyle ki hem ticaret hem de sivil taşımacılık adına atılan önemli adımlar arasında yer alır. İstasyonların bulunduğu caddeler ise kent içerisinde merkezi yere konumlandırılırlar. Dolayısıyla bulvar, meydan, kamu yapıları dizgisinde yer alan istasyon caddeleri de yeni kentsel yaşamın vurgusunu taşır. Tabii kent planlamasının en yeni ve belki de en önemli paylaşım alanını parklar oluşturur. Yeni kurulan kamusal alanların ve sanayi yapılarının çalışanları için hem paylaşımcı hem de nefes alınacak yerler olan parklar için Tanyeli önemli bir başka vurgu yaparak buraların kadınlı erkekli paylaşım alanı olması ile aslında seküler ve kolektif özellik gösteren, kentsel modelleme örneğinden söz eder (Tanyeli, 1998:101-102).

Kentsel ölçekte yeni kent planlama pratikleri ile olduğu kadar 1930'lar ekonomik anlamda yeni Cumhuriyet devleti için bir dönüm noktası olur. Amerika Birleşik Devletleri'nde başlayan ve tüm dünyaya yayılan ekonomik krizin etkileri Türkiye'yi de etkileyecek ve devleti ekonomik anlamda devletçi politikaya yakınlaştıracak (Yücel, 2015:17), yeni sanayi alanları ve yeni iş kollarını da gündeme taşıyacaktır. 


\section{SDÜ ART-E}

Güzel Sanatlar Fakültesi Sanat Dergisi

Haziran'20 Cilt:13 Sayı:25

ISSN 1308-2698

Aslında devletçi politikanın yanı sıra 1930'lara hâkim olan ulusçuluk kavramının altında ülkeyi Türk kültürüne bağlı bir bütün olarak görme isteği yer alır. Bir tür "kültür milliyetçiliği" olarak nitelenebilecek olan gelişme, Türklerin ulusal ve tarihi özelliklerine uygun bir politikayı öngörürken, bu düşünce Atatürk tarafından da ele alınır ve bilimsel kurumlarca gelişimi sağlanır (Yasa Yaman, 1996:29). Bu dönemde benimsenen sanatın toplumlar arasında etkin bir iletişim aracı olduğudur. 1940'lı yılların ortalarına kadar kültür ve eğitim üzerine odaklanılan kurumlaşmalarda sanatın dönüştürücü etkisinden yararlanmak amaçlanır. Sanattaki değişimin kaynağında toplum yer alırken, programlanması da devletin politikaları doğrultusunda olur (Yasa Yaman, 1996:31). 1938 yılının Temmuz ayı gazeteleri, resim sanatı ve ressamları doğrudan ilgilendiren bir haberi yayımlar (Giray, 1995:34). Bu "mühim mevzu" ve "müsbet karar"; Yurt Gezileri ve Sergileri'ne atılan ilk adımı haber verir. Aslında 1932'de Halkevleri açılır, 1933-1937 yılları arasında da İnkılâp Sergileri düzenlenir. 1940'lara gelindiğinde ise Köy Enstitüleri kurulmaya başlar. Amaç hep kırsal bölgeyi kalkındırmaya yöneliktir; ancak söz konusu çabalar köylüyü kentteki halkevine çekmeyi başaramaz. Dolayısıyla ortaya yeni görüş olarak Yurt Gezileri çıkar. Amaç halka resim, heykel gibi plastik sanatları tanıtmak, sevdirmek ve öğretmektir (Berk ve Özsezgin, 1983:69-74). Devlet tarafından seçilen sanatçılar yine devletçe belirlenmiş olan Anadolu şehirlerine gidecekler önce eskizler çalışacak sonra da bu çalışmalardan resim üreteceklerdir. 1938-1943 yılları arasına tarihlenen Yurt Gezilerine toplam 48 sanatçı katılır (Öndin, 2003:108-109). 64 şehir ve 1 ilçeye gönderilen ressamlarca 675 adet resim üretilir ${ }^{1}$.

Aslında devlet destekli sanat programları, Yurt Gezilerinde olduğu gibi devletin ya da dönemin kültür politikasının sanata yaptığı yatırımlarının somut verilerini içerir (İskender, 1996:44). Söz konusu etkinlik kendilerini büyük kentlerle sınırlandırmış olan sanatçıların hem yeni yerler görmesini sağladığı gibi hem de devlet destekli yapılan eserlerin sanatçılara belirli bir maddi kazanç sağlaması açısından da önemlidir (Öndin, 2003:109). Bu bağlamda ilk Devlet Resim ve Heykel Sergisi 29 Ekim 1939'da başlatılır (Tansuğ, 1986:217), ressamlar da

\footnotetext{
${ }^{1}$ Bkz. http://www.millireasuranssanatgalerisi.com/sergiler/-cumhuriyetin-romansi-yurt-gezileri-1938-1943, Erişim tarihi: 06.03.2020.
} 
Anadolu'nun çeşitli yerlerine gönderilmeye devam eder. Bu esnada Şeref Akdik de üçüncü dönemde 1940' da İçel'e, 1943'te Erzincan'a gidecektir (Elibal, 1974:28, 29).

\section{3. Şeref Akdik ve Resimlerine Yansıyan Kentlileşme Olgusu}

Erken Cumhuriyet Dönemi'nin önemli isimlerinden olan Şeref Kâmil (Akdik), 1899'da İstanbul'da doğar. Meşrutiyet dönemi İstanbul'unda yetişir. İçinde doğduğu ortamın ve sahip olduğu sosyal çevrenin sağladığı imkânlar sayesinde iyi bir eğitim alır. Babası Reisülhattatin payesini taşıyan büyük hattat Ahmed Kâmil (Akdik)'in teşvikiyle resim sanatına yönelir. 1911'de Osmanlı Ressamlar Cemiyeti'nce çocuklar için düzenlenen müsabakaya katılır ve ikincilik ödülünü alır. Artık önünde açılan yol, resim sanatında eğitim almasına teşvik edecektir. 1915'te Sanayi-i Nefise Mektebi'ne girer önce Varnia Zarzecki'nin daha sonra da İbrahim Çallı'nın öğrencisi olur. Öğrencilik yılları Birinci Dünya Savaşı'nın yaşandığı İstanbul'da geçer (Elibal, 1974:11). Öyle ki bir dönem resim eğitimine ara verecek ve savaşa katılacaktır. 1918'de savaşın bitişi ile resim eğitimine kaldığı yerden devam eder.

1924'te Sanayi-i Nefise Mektebi'nden mezun olduğunda ülkede de yönetim şekli değişmiş, Cumhuriyet rejimine geçilmiştir. Yeni Türkiye Cumhuriyet'inde kuruluşundan itibaren ilk on yıllık süreç, pozitivist temele dayandırılır. Halkçılık, ulusçuluk bilim kavramları bu temelin özünü oluşturur (Yasa Yaman, 1996:29). Artık Türk sanatı için yeni bir kültür dönemi başlayacaktır. Cumhuriyetin sanat ve eğitim alanında ilk kalkınma programlarından biri de öğrenim ilkeleri olur. Dolayısıyla Maarif Vekâletince bir konkur düzenlenecek ve başarılı olanlar Avrupa'ya eğitime gönderileceklerdir. Aslında 19. yüzyılda başlayan ve gelenek haline gelen eğitim anlayışının devamı niteliğindeki bu uygulama ile Şeref Kâmil (Akdik), Mahmut (Cûda), Muhittin (Sebati), Refik (Epikman), Cevat (Dereli), jüri tarafından seçilerek, Cumhuriyet Dönemi'nin Paris'e giden ilk ressam grubunu oluşturur (Giray, 2004:18).

Paris'te Académie Julian'da Albert Laurens'in atölyesine devam eder. Akademi dönemini iyi değerlendirir ve tatillerinde Paris'in dışına çıkar; Almanya'ya gider. Burada Ali Avni (Çelebi) ve Zeki (Kocamemi) ile birlikte zaman geçirir, müzeleri gezer. Sonra Brüksel’e oradan İtalya'ya geçer (Elibal, 1974:16). Döneminin sanat adına yaşanan bir diğer önemli gelişmesi de, sonradan Müstakil Ressamlar ve Heykeltıraşlar Birliği adını alacak olan Yeni Resim Cemiyeti'nin 


\section{SDÜ ART-E}

Güzel Sanatlar Fakültesi Sanat Dergisi

kurulmasıdır. Cemiyetin ilk sergisi, 15 Mayıs 1924'te İstanbul Matbuat Cemiyeti binasında gerçekleşir. Sergiye Şeref Kâmil (Akdik), Elif (Naci), Refik Fazıl (Epikman), Mahmut (Cûda), Ali Avni (Çelebi) gibi sanatçılar katılır. 16 Temmuz 1928'de yurda döndükten sonra Ankara Gazi Terbiye Enstitüsü’nde resim hocalığı yapar. 15 Temmuz 1929'da kurulan Müstakil Ressamlar ve Heykeltıraşlar Birliği'nin kurucuları arasında yer alır. Bu dönem resimleri somut bir bakışa sahiptir. İnsan ve çevresi ile olan ilişkilerini inceleyen Akdik için, yapı sağlamlığı önemlidir (Gören 2003a:125; Gören 2003b:27). 1939'da California/San Francisko'da 79 ünlü ressamın sergisinde Pazar'dan Dönüş tablosu ile madalya alır.

Paris'ten döndüğünde Cumhuriyet ile birlikte toplumsal dönüşümlerin yaşandığı bir düzenin içine gelir. Kamusal mekânlar değişir ve dönüşürken, beraberinde sanayileşmeyi, kent olgusunu ve kentlileşmeyi de birlikte getirir. Kent imgesi oluşurken ulaşım ağı, yeni park alanları, kentli insanlara uyumlanmaya çalışan fabrika çalışanları da artık görünür olmaya başlayacaklardır. Ressam Şeref Akdik de söz konusu ortamda daha çok yeni kent merkezlerini, fabrikaları, fabrika işçilerini döneminin toplumsal gerçekliği içinde ele alarak resimlerine yansıtır. Onun çalışmaları kuşkusuz Türkiye modernleşmesinde önemli bir yerdedir. Betimlerinde fabrikaları düzen ve uyum içinde ışıkla kaplanmış, keyifli üretim yerleri olarak gösterirken, aynı zamanda da fabrikalaşmanın ülkenin ekonomik gelişimine olumlu olduğu düşüncesini yansıtır (ileri, 2007:167). Çalışmalarında karşımıza çıkan işçiler, kentte yeni oluşmaya başlayan bir sınıfın varlığına da işaret eder (Görsel 1-2). Üstelik kadınlar da bu yeni iş gücünün içerisinde önemli bir yer edinecek, ilerleyen dönemlerde bağımsız, güçlü işgücünün de temsilcisi olacaklardır. Nitekim Tütün İşleyen Kadınlar'da bir atölyede çalışan, üreten kadınları betimler. 1940'lı yılların değişen toplumsal düzenini ve fabrikada çalışan kadınların üretime katkılarına işaret ederken, bir başka çalışmasında metalurji fabrikasında çalışanları konu olarak alır (Görsel 2). 


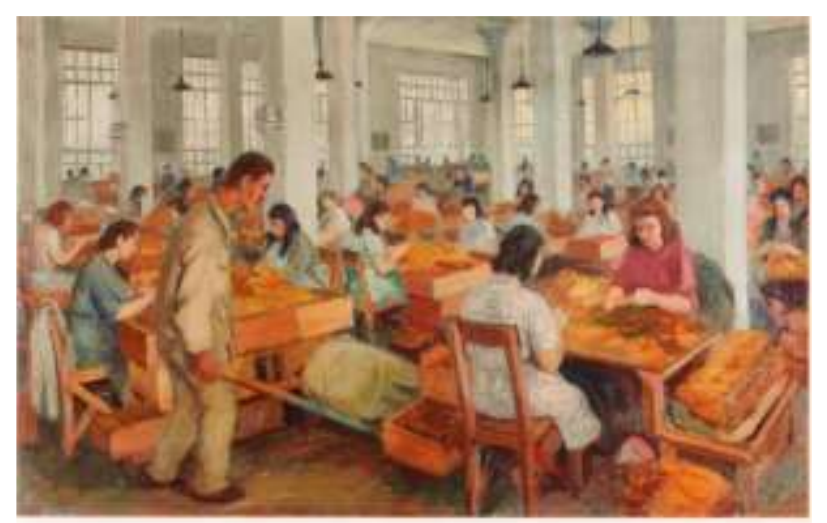

Görsel 1. Şeref Akdik, Tütün İ̧sleyen Kadınlar, yaklaşık 1940, tuval üzerine yağlıboya, 55x86 cm, İstanbul Modern Sanat Müzesi.

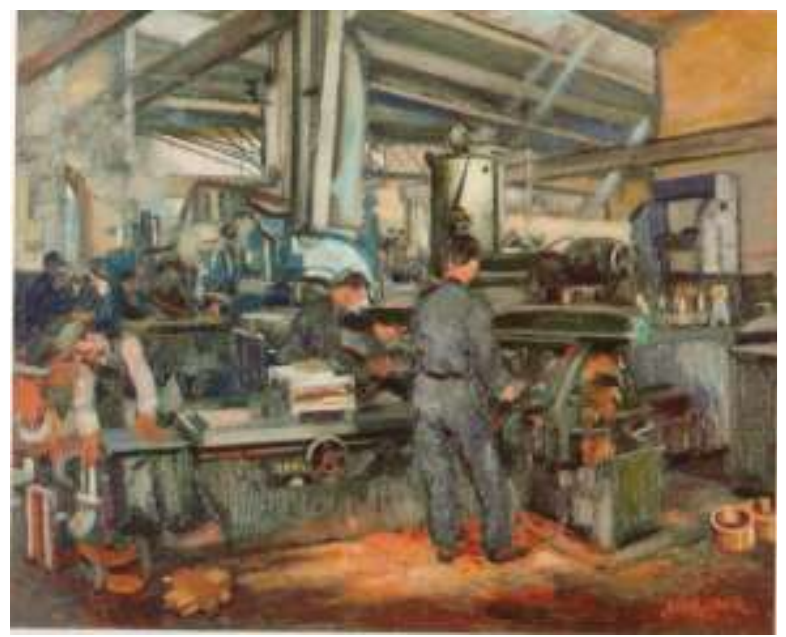

Görsel 2. Şeref Akdik, Metalurji Atölyesi, 1945, tuval üzerine yağııboya, $54 \times 65$ cm, İstanbul Modern Sanat Müzesi.

Dönemin politikası ile uyumlu devletçi bir bakışın hâkim olduğu çalışmalar yapar ve kendisini şöyle tanımlar: "Eserlerim kendi görüş ve duyuşumun mahsulüdür" (Özden'den akt. Öndin, 2003:256). 1946 yılına tarihlenen Eskişehir ve Sivas'taki Cer Atölyelerini çalışan Akdik, üretime ve gelişmeye odaklanan Cumhuriyet'in politikasını da birebir yansıtmayı başarır (Görsel 3,4). Eskişehir Cer Atölyesinde büyük bir atölyeyi ve dev lokomotif tekerleklerinin yanında çalışanları betimler. İşçileri tekil olarak tamamen kendi işine odaklanmış, güçlerini birlikte var etme duygusundan alan bireyler olarak gösterir. Şeref Akdik, Kurtuluş Savaşı'ndan bir harabe olarak çıkmış Eskişehir'e sadece ekonomik değil, aynı zamanda sosyal ve kültürel bir dönüşüm de yaşatan bu büyük atölyeyi ve var gücüyle köprü, makas, buharlı lokomotiflere kazan üreten, 
lokomotif montajında çalışan işçileri resmederken, dönemin ruhuna da vurgu yapar (Okkalı, 2014:464). Erken Cumhuriyet'in politikalarından biri olan ulaşım ağı ve demiryolları belki de en önemli örneklemesini Eskişehir'de verir. Cumhuriyet'in ilk ve uzun soluklu tek ağır sanayi kuruluşu olan Cer Atölyesi; ray döşeme, vagon, lokomotif onarımının yanında Cumhuriyet'in gelişiminde önemli bir paya da sahiptir (Okkalı, 2014:464).

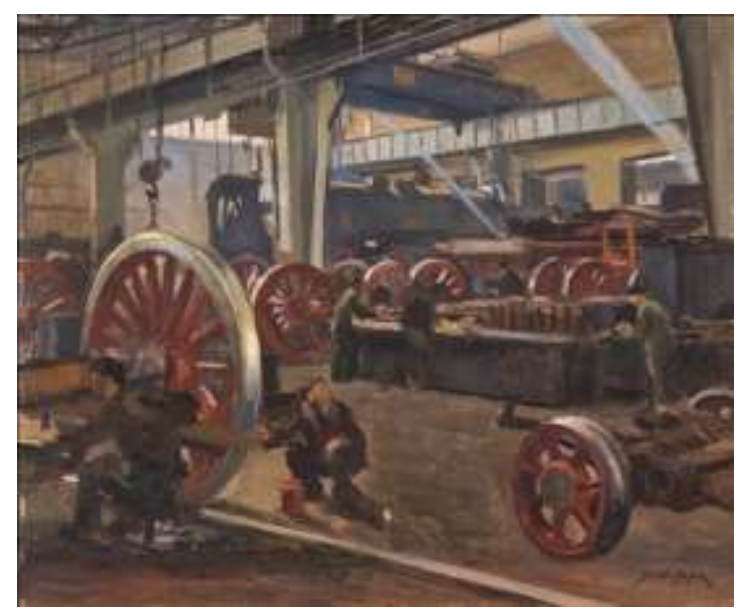

Görsel 3. Şeref Akdik, Eskişehir Cer Atölyesi, 1946, mukavva üzerine yağlıboya, $55 \times 65$ cm., Akbank Koleksiyonu.

Eskişehir'le birlikte Sivas'taki Cer Atölyesini de betimler (Görsel 4). Çalışmasında ray döşeme, vagon, lokomotif onarımı için kurulmuş atölyeyi ve dev lokomotifin yanında çalışanlarıyla birlikte konu alır.

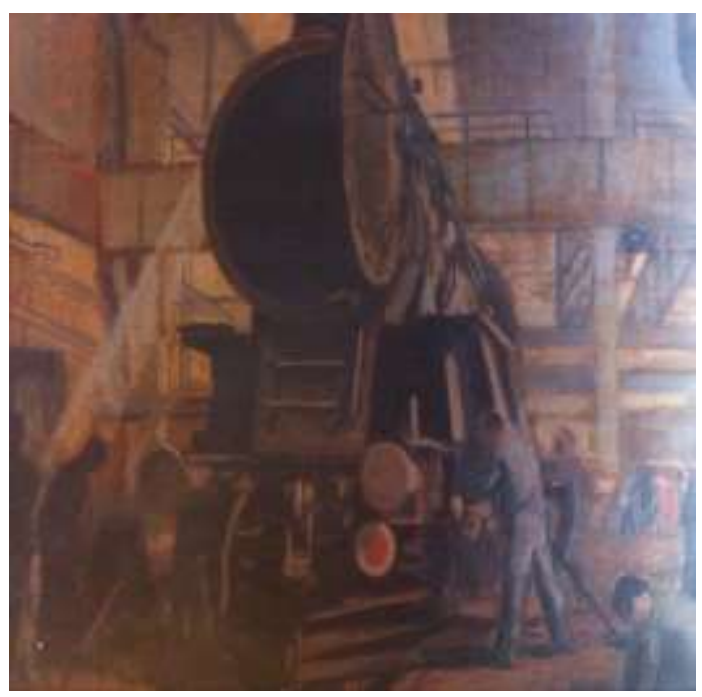

Görsel 4. Şeref Akdik, Sivas Cer Atölyesi, 1946, tuval üzerine yağlıboya, 55x65 cm, Akbank Koleksiyonu. 


\section{SDÜ ART-E}

Güzel Sanatlar Fakültesi Sanat Dergisi

Haziran'20 Cilt:13 Sayı:25

ISSN 1308-2698

Cer Atölyeleri kuşkusuz yeni Cumhuriyet Türkiye'si için önemli adımlardan biridir. Akdik de konu olarak bu atölyeleri çalışmayı tercih eden, inkılâpçı bir ressam olarak çıkar karşımıza. Onun resimleri mekânsal olarak incelendiğinde yaşayan ve üreten insanların vurgulandığı görülür. Geniş açıdan ve yukardan betimlediği çalışmalarında atölyelerde çalışan insanlara ve teknolojinin varlığına dikkat çeker (Okkalı, 2014:465-466). Aslında Akdik, inkılâpçı olmanın yanı sıra teknolojiye de meraklıdır. Ressam Osman Altıntaş Paris'e gittikten sonra Şeref Akdik'in teknolojiye olan ilgisinin arttığından söz eder ve şöyle aktarır:

Burada (Paris'te) sanatçı endüstri ve teknolojik gelişmeleri yakından izleme fırsatı buldu. Bunların fert üzerinde ne gibi etkiler yarattığını inceledi. Fırsat buldukça Fransa dışındaki diğer bazı Avrupa ülkelerinde gelişen diğer sanat hareketlerini de tanıma fırsatını da elde eden Akdik, sanatın hakiki kültürün ayrılmaz bir parçası olduğu fikriyle o yıllarda gerçek bir sanat inkılâbı sayılan, içinden geldiği toplumun, kolayca anlayabileceği bir sanat anlayışını benimsedi ve hiçbir zamanda bu inandığı yoldan taviz vermedi (Altıntaş, 1988:23).

1930'lardan 1950'lere uzanan süreçte sanayileşme girişimlerinin yanı sıra kentsel ölçülerde ve yaşam pratiklerindeki gelişim ve değişimler de Akdik'in resimlerinde işlenen konular arasında yer alır. 1933'de Kadıköy Erkek Lisesi Öğretmenliği, 1934'den itibaren de ek olarak Haydarpaşa Lisesi Öğretmenliği yapan sanatçı, yaşamını sürdürdüğü Kadıköy ve Moda'dan Sarayburnu ve Marmara Denizi'ne bakarak İstanbul'un değişen kent yaşamını betimler. Kadıköy'den bakışla Haydarpaşa Garı'nı ve Galata Köprüsü'nü betimlediği çalışmalarında 1945 ve 1955'li yılların İstanbul'unda otomobiller, kamyonlar, vapurlar, köprüde insan kalabalığı, hava kirliliği gibi değişen yaşamı gözler önüne serer (Görsel 5, 6). Haydarpaşa Garı'nı betimlediği çalışmanın literatürde ismi belirtilmemiş olsa da bu çalışma, İstanbul Haydarpaşa Garı olarak nitelenebilir (Görsel 5). Söz konusu çalışmalar, kentsel ölçekte meydan ve meydanları birbirine bağlayan köprü gibi kamusal alana vurgu yapan çalışmalar arasında yer alır. 
SDÜ ART-E

Güzel Sanatlar Fakültesi Sanat Dergisi

Haziran'20 Cilt:13 Sayı:25 ISSN 1308-2698

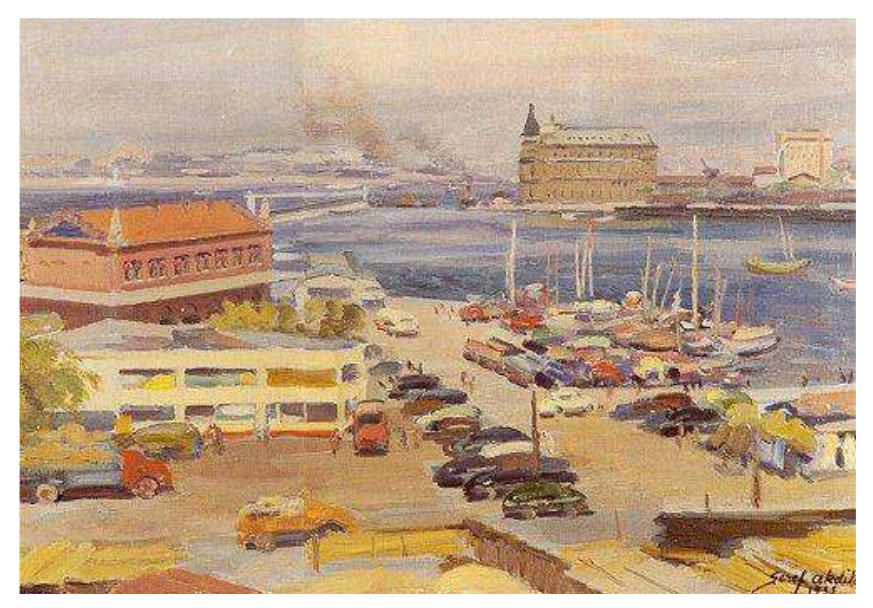

Görsel 5. Şeref Akdik, Haydarpaşa Garı, 1955, tuval üzeri yağlıboya.

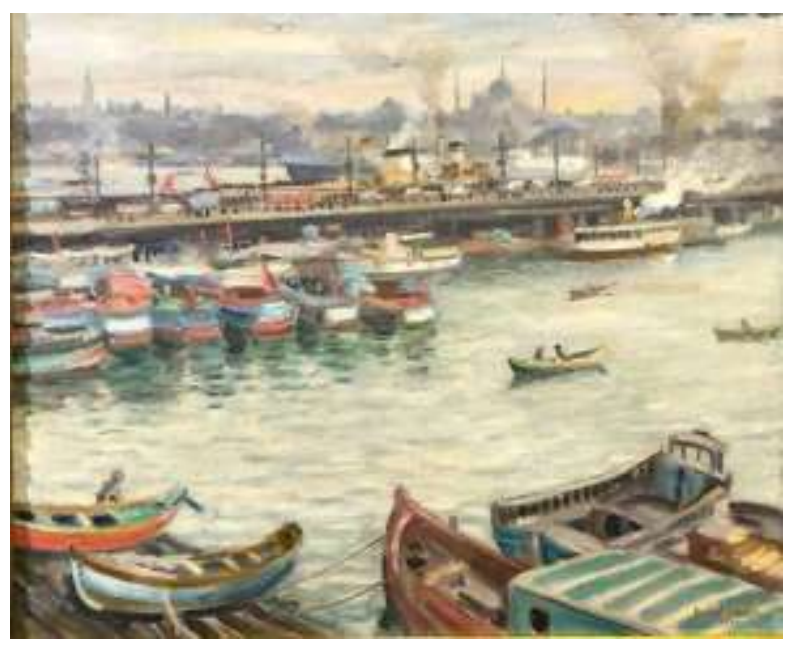

Görsel 6. Şeref Akdik, Galata Köprüsü, 1961, tuval üzeri yağlıboya, 51 x 61 cm.

Cumhuriyet'in getirdiği kentsel Modernist pratikleri arasında park ve bahçeler de önemli ölçüde rol oynar. Parklar, çay bahçeleri yeni oluşan mekânlardaki modern kentliliğin göstergeleri olarak Şeref Akdik'in resimlerinde de karşımıza çıkar (Görsel 7, 8, 9). Akdik'in resimlerine Moda ve çay bahçesi sıklıkla konu olur. Resimlerinde ışık önemli bir öğedir. Işığı adeta formun (biçimin) kaynağı olarak kullanır. 
SDÜ ART-E

Güzel Sanatlar Fakültesi Sanat Dergisi

Haziran'20 Cilt:13 Sayı:25

ISSN 1308-2698

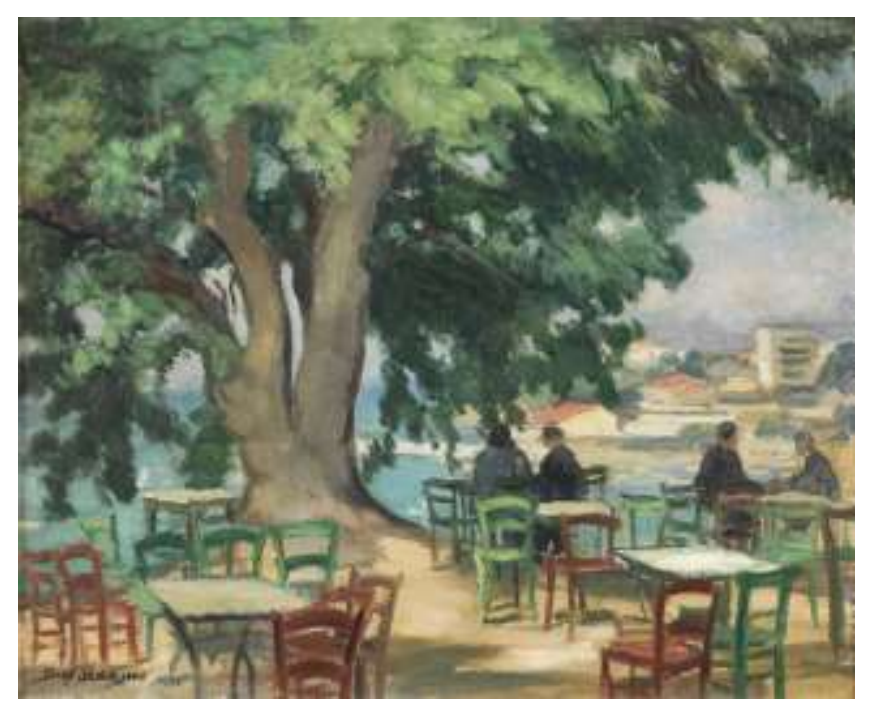

Görsel 7. Şeref Akdik, Moda Çay Bahçesi, 1945, tuval üzeri yağlıboya, $38 \times 47 \mathrm{~cm}$.

Ayrıca parklar ve bahçeler kadınlarla erkekleri bir araya getiren seküler sistemin en önemli temsilcisi olarak da ayrı bir öneme sahiptirler. Özellikle idealize edilmiş yeni kadın imgesi, Akdik'in resimlerinde betimlenen konular arasında yer alır. Modern giyimli entelektüel Cumhuriyet kadını, eskinin kadınlarına karşı gururla kıyaslanabilir niteliktedir (Bozdoğan, 2008:98). Nitekim Şeref Akdik'in 1950 sonrasına tarihlenen kalabalık sahneli betimlerinde parklar ve çay bahçelerinde kadın-erkek birlikte oturup sohbet ederken çıkar karşımıza. Bu döneme ait bol figürlü çalışmalarında yüzleri soluk ve belirsiz çalışır.

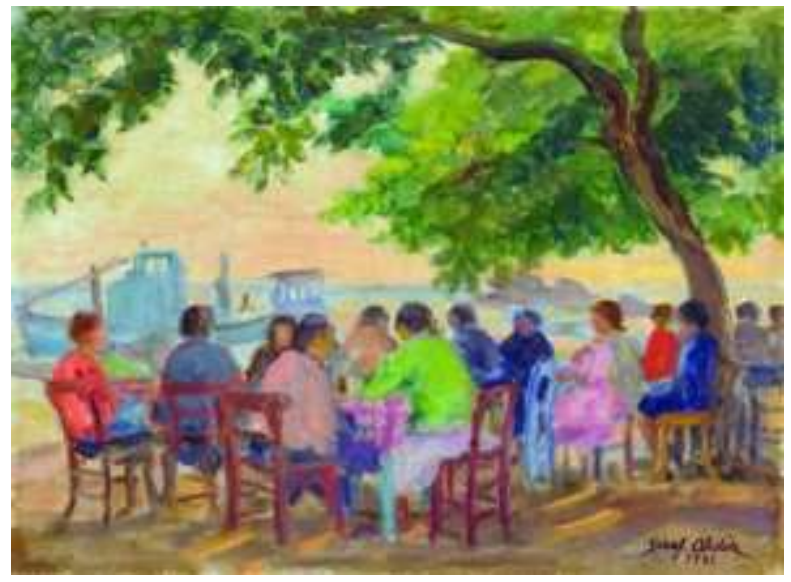

Görsel 8. Şeref Akdik, Çay Bahçesi, 1961, tuval-sunta üzerine yağlıboya, 27x34 cm. 


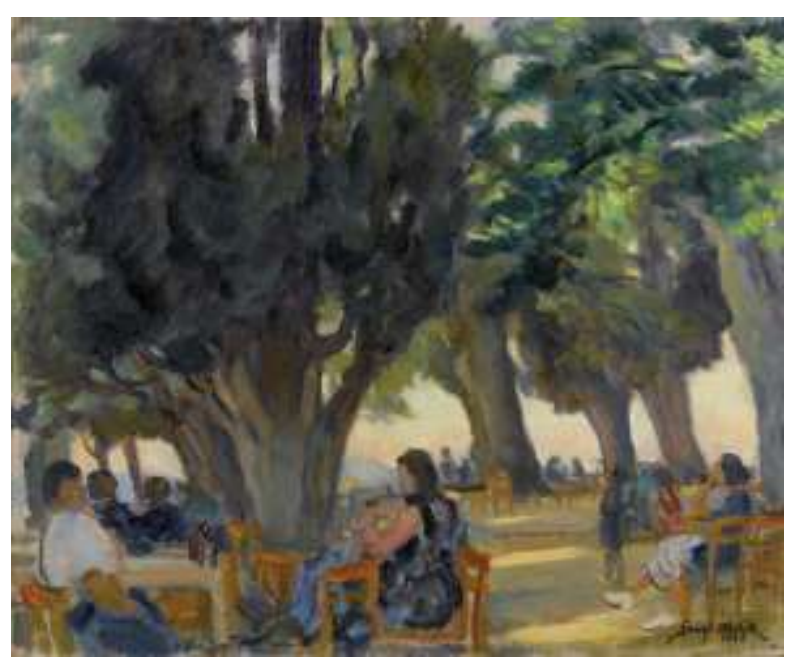

Görsel 9. Şeref Akdik, Moda Çay Bahçesi, 1952, Yağlıboya.

Cumhuriyet ilan edildiğinde devlet bir modernleşme olgusu içindedir. Kurtuluş Savaşı'nın getirdiği ekonomik yıkımdan sonra endüstrileşme, Türkiye modernizasyonunun önemli bir parçasını oluştururken, aynı zamanda siyasi olarak da yeni bir ulus devletin inşası söz konusudur. Milli birliğin amaçlandığı bu yıllarda devrimler gerçekleşir ve devrimlerin getirdiği değişimleri halka gösterme düşüncesi önem kazanır. Özellikle resim sanatı bu anlamda büyük bir rol üstlenir. Devlet tarafından programlı düzenlenen Yurt Gezileri ile ülkenin farklı yerlerine giden sanatçılar, modernleşen Türkiye'yi resmederler. Devletin resmî politikası çerçevesinde resimler yapılır. Döneme hâkim olan genel düşünce yeni fabrikaları, fabrikaların düzen içindeki ortamlarını, gelişen ulaşım ağını ve yeni kamusal binaları ile meydanları betimlemektir. Amaç ülkenin ekonomik gelişimine olan olumlu bakışı yansıtmaktır (ileri, 2007:167). Bedri Rahmi Eyüboğlu'nun Illk Geçen Treni Seyreden Köylüler (1935), ile Kömür Ocakları (t.y.), Cemal Tollu'nun Antalya'da yaptığı Akköprü Ziraat Istasyonunda Köylüler (1938), Liman ve Un Fabrikası (1938), Sabiha Rüştü Bozcalı'nın Zonguldak'ta yaptığı Kozlu Elektrik Santrali (1939), Skip Tesisatı (1939), Karabük Demir Çelik Fabrikası (1939), Asansör Makinası (1939), Sömikok Makinası (1939), Demir Çelik Fabrikası (1939) gibi makineleri, sanayileşmeyi ve üretimi konu alan resimleri ile aynı milli duygularla, ancak söz konusu gezi kapsamında olmayan Nurullah Berk'in Tayyareciler'i (yak. 1933), endüstrileşmeyi örnekleyen çalışmalar arasında yer alırken (Berk, 2010:38, 39, 53, 57); Akdik'ten daha erken döneme tarihlenen Şevket Dağ'ın İstanbul Limanı (1930), Haydarpaşa Garı (1930), İmir Limanı-Alsancak Garı (1924) ve Demiryolu (1936) 
SDÜ ART-E

Güzel Sanatlar Fakültesi Sanat Dergisi

Haziran'20 Cilt:13 Sayı:25

ISSN 1308-2698

çalışmaları, gelişen ulaşım ağını betimleyen örneklerdir. Refik Epikman'ın Ankara'dan Görünüm (1942), Nazmi Ziya Güran'ın Taksim Meydanı (1935), Mahmut Cûda'nın Trabzon Parkı (1938) ve Eşref Üren'in Taksim (1950) resimleri dönemin değişen kent siluetine, modern kıyafetli insanlara, değişen ulaşım araçlarına vurgu yapan çalışmalardır.

Devletçilik ve ulusçuluk ilkesi bağlamında betimlenen Berk'in Tayyareciler resmi bir havacılık sahnesidir. Sibel Bozdoğan'a göre uçak ve uçuş, modern algının önemli bir metaforu olup, yeni Türkiye'nin bakış açısında yer alır (Bozdoğan, 2008:415). Dolayısıyla Berk'in resmi, Türkiye'de gelişen teknolojinin göklerdeki yansıması olarak önemli çalışmalar arasında yer alırken Ressam Aydın Ayan, Eyüboğlu’nun Treni İzleyen Köylüler çalışmasında işlenen benzer modernleşme olgusunun var olanı değil, daha çok öykünülen bir durumu betimlediğinden söz eder (Ayan'dan akt. Dellaloğlu Dastarlı, 2018:415, 423). Bu bağlamda aynı dönemin sanatçıları ile birlikte aynı konuları, aynı ülküsel yorumu çalışan Şeref Akdik'in resimleri için bir farklılaşma söz konusu mudur? Aslında Akdik'in çalışmaları resimsel bir yorumdan çok, içinden geldiği toplumu ifade eder. Dönemin diğer sanatçıları ile birlikte kültür politikasına paralel resimler yapar; ancak onun çalışmaları sadece yurt gezileri ile sınırlı kalmaz. Devletçilik ilkesini bütünsel olarak benimser ve çalışmalarında toplumun her katmanında yaşanan değişimleri vurgular. Dolayısıyla her bir resmi, Erken Cumhuriyet Dönemi'nin yansımasını taşır.

Cumhuriyetin kuruluşundan itibaren 1950'li yıllara kadar hem siyasi hem de toplumsal anlamda yaşanan değişimler, devletçilik ilkesi altında tek partili dönemde gerçekleşir. 1950'lilere gelindiğinde ise çok partili dönemin başlaması ile dönemin iktidar partisi ülkeye farklı bir yaklaşım getirir. Bu dönemde devletçilik anlayışı yerine liberal serbest pazar ekonomisi desteklenecek, Batılı sistemin koşullarına uyum sağlamak üzere yeni arayışlar içine girilecektir. Bu çerçevede köyleri dışarı açan yollarla birlikte başlayan köyden kente göç, kentteki nüfus artışını desteklerken (Yasa Yaman, 2012:323), sanayileşme ile ortadan kalkmaya yüz tutan halk sanatına ilgi de artmaya başlayacaktır (Tansuğ, 1986:233). Güçlü ve idealize edilmiş kadın betimlerinin yanı sıra kadın gücünün vurgulandığı geleneksel sanat çalışmalarına da yer verilmeye başlanır. Akdik de 1950'li yıllara tarihlenen, kadınları çini boyarken betimlediği bir seri resim yapar. (Görsel 10, 11, 12). Canlı tonların hâkim olduğu Çini Yapanlar adlı resimde 
SDÜ ART-E

Güzel Sanatlar Fakültesi Sanat Dergisi

Haziran'20 Cilt:13 Sayı:25

ISSN 1308-2698

soğuk ve sıcak renkleri bir arada kullanır. Çalışmasında es-pas kullanarak öndeki figürleri ön plana çıkarır. Geleneksel bir konu olan çiniyi çalışan kadınlar, yerel kıyafetler içindedirler.

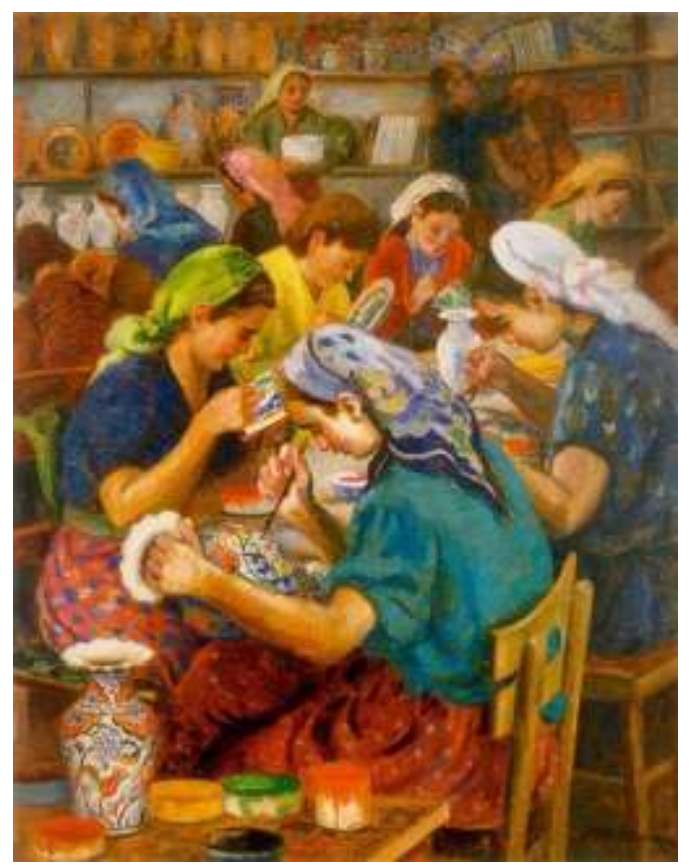

Görsel 10. Şeref Akdik, Çini Yapanlar, 1956, Duralit Üzeri Yağlıboya, 115 x 88,5cm, TCMB Koleksiyonu.

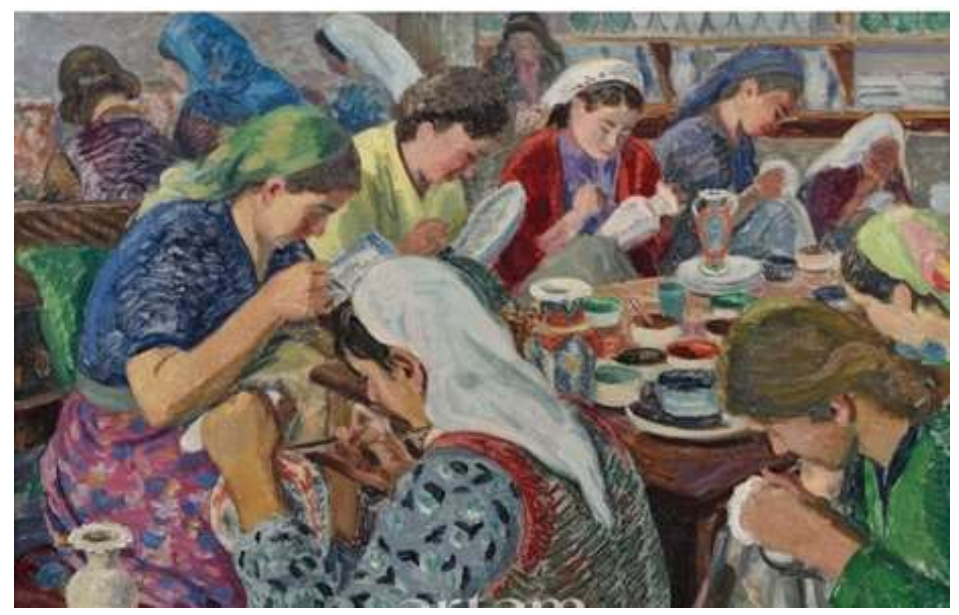

Görsel 11. Şeref Akdik, Çini Atölyesi, detay, 1955, tuval üzerine yağlıboya, 60x71 cm. 


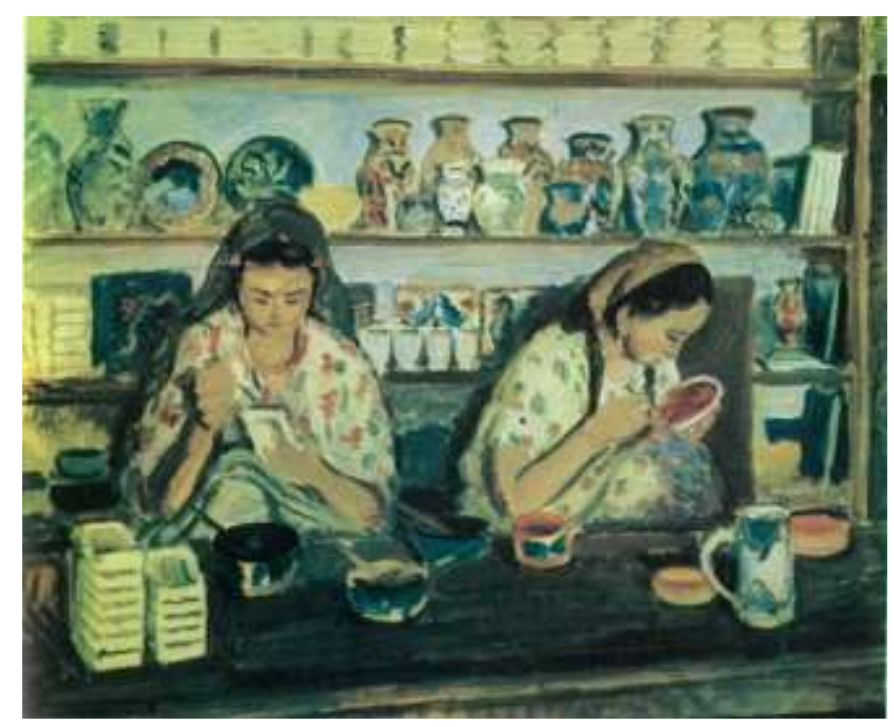

Görsel 12. Şeref Akdik, Çinici Kızlar, 1955, Tuval Üzeri Yağııboya, 56x66cm.

1951'de Devlet Güzel Sanatlar Akademisi öğretmenliğine atanan (Elibal, 1974:73,74), Akdik, 1958'lerde Moda'da özel bir atölye kurar. 1964'te Devlet Güzel Sanatlar Akademisi'nden emekli olur. 1972'de vefat eder. Yaşadığı topluma duyarlı bir sanatçı olan Akdik, çalışmalarını toplumsal gerçeklik içerisinde gerçekleştirir. İzlenimci bir ressamdır aslında ve resimlerinde ışık ve gölgeyi dönemin çizgileri içinde içselleştirerek kullanır. Sert konturların kullanılmadığı betimlerinde kompozisyonları renk, ışık ve nesneleri ile eksiksizdir. Kompozisyon kurgusunda bütünlük söz konusudur. Renk ve tonlamalarının, güçlü desen anlayışla birleştirdiği çalışmaları büyük bir titizliğin ürünü olsa gerektir. Nitekim Şeref Akdik hakkında yazan İsmail Hakkı Baltacıoğlu, sanatçının resimlerini şöyle anlatır:

"Şeref, tekniği, estetik akımları her ne olursa olsun zamanını, zamanın sosyal zaruretlerini anlamış bir insandır. Görülüyor ki memlekette bir değişme, olgunlaşma hareketi vardır ve bu yalnız politika alanında değil, köyde, şehirde, teknikte, terbiyede, her yerde ve her işte. Onun için Şeref'in resimlerinin ilk karakteri sosyal ve inkılâpçı olmasıdır" (Baltacıoğlu’ndan akt. Giray, 1997:155).

Modernleşme olgusunda yer alan önemli göstergelerden biri de eğitim vurgusu ve açılan okullardır. Toplumsal gerçeklik içinde dönemin değişimlerini resimlerine aktaran Akdik, Okuma Yazma Kursu/Millet Mektebi (1933) (Görsel 13), Köylüler Resim Elişi Dersinde/Köy Enstitüsünde Ders (1935) ve Mektebe Kayıt (1935) adlı çalışmalarında devrimin oluşum 
sürecinde Atatürk'ün eğitime verdiği önem konusuna değinir (Öndin'den akt. Okkalı, 2014:446). Yeni Latin alfabesiyle ülke çapında bir okuma-yazma kampanyası düzenlemek, Tevhid-i Tedrisat Kanunu'nu çıkartmak, Cumhuriyet Dönemi'nin ilk eylemleri arasında yer alır. O döneme ait fotoğraf ve resimler, eğitim temasının kültürel önemine tanıklık eder. Bu resimlerde üniformaları içinde sağlıklı okul çocukları, okuma-yazma dersi alan kadınlar ve oğlanlarla kızların bilimsel bir eğitim ve Cumhuriyet idealleriyle tanıştıkları karma öğretim yapılan köy okulları tasvir edilir (Bozdoğan, 2008:104). Modern eğitimin gereği, kız ve erkek çocuklarının eğitimden eşit bir şekilde yararlanmasını hedefleyen karma okullar, aynı mekân ve sistem içinde eğitim ilkesinden hareketle, yalnızca öğrencilerin değil, öğretmenlerin de cinsiyet fark etmeksizin aynı ortam içinde çalışmasına olanak sağlar (Öndin, 2003:211).

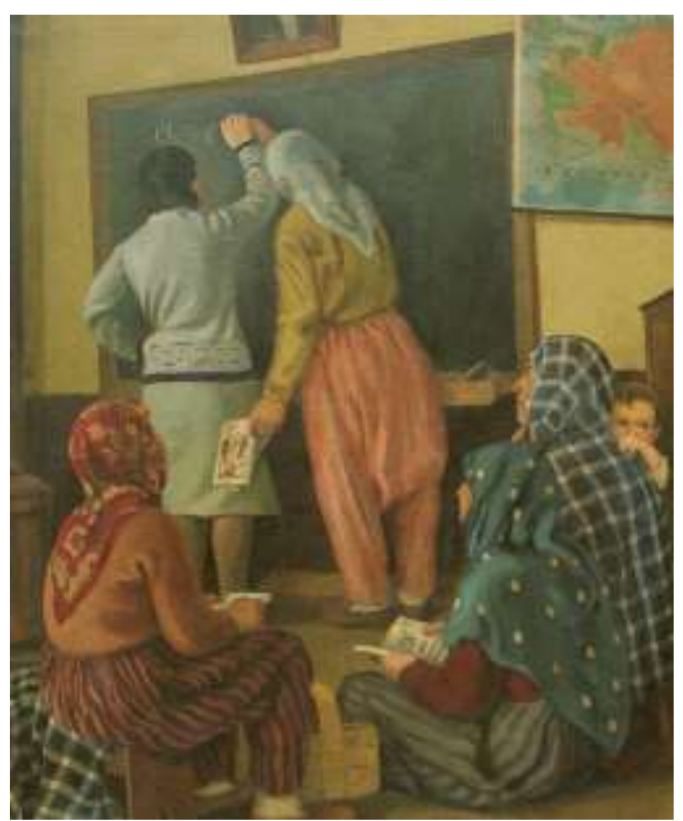

Görsel 13. Şeref Akdik, Okuma Yazma Kursu/Millet Mektebi, 1933,Tuval Üzeri Yağııboya, 180x150 cm, MSGSÜ-iRHM.

Şeref Akdik çoğu resimlerinde geleneksel tekniğe bağlıdır. Ancak geleneksel tekniği, üsluplaştırmadan kullandığını ya da gördüğünü resmettiğini söylemek doğru bir yaklaşım değildir. Doğadaki dış nesneleri kopya eder gibi göründüğü halde gerçekte onları bambaşka kalıplarla ve üsluplaştırmalarla işler. Dış görünümlere bağıı kalmakla beraber özellikle tek figür ve portrelerinde, erken Cumhuriyet Dönemi ressamları arasında saygın bir yer alır (Ülker ve diğerleri, 2014:48-50). Malik Aksel, Akdik'in figür ve manzaralarında büyük bir sadelik ve sükûnet bularak olgun bir pentür anlayışından bahseder (Aksel, 1942:3). 
SDÜ ART-E

Güzel Sanatlar Fakültesi Sanat Dergisi

Haziran'20 Cilt:13 Sayı:25

ISSN 1308-2698

\section{Sonuç}

1923'te Cumhuriyetin ilanı ile başlayan Modernist yaşam pratikleri içerisinde yer alan kentlileşme, kentli olma olgusu ve beraberinde getirdiği yeni sosyal yaşam, 1950'lere kadar gelişerek devam eder. Özellikle tek partili dönemin devletçi politikası altında gelişen Modernist çalışmalar içinde yeni sanayi, yeni iş kolları ile oluşan yeni işçi sınıfı, hem ticari hem de sivil taşımacılığı gerçekleştiren ulaşım ağı yer alırken aynı zamanda sanat ve sanatçılarda ulusallaşma altında oluşan kültürel milliyetçiliğin gelişiminde önemli rol oynarlar. Bu dönemde devlet destekli Halkevleri açılacak, sanatçılar Anadolu'ya gönderilerek kırsal bölge yaşayanı da yeni sanat ortamıyla tanışmış olacaktır. Bu çalışmanın konusu olan Cumhuriyet Dönemi sanatçıları arasında yer alan Şeref Akdik de İnkılâpçı ve devletçi bir ressamdır. Müstakil Ressamlar ve Heykeltıraşlar Birliğinin üyesidir. 1940'larda Yeniler Grubu gibi çağdaşı olan diğer sanatçılar farklı temaları çalışmayı denerken, Akdik, yeni kurulan Cumhuriyet'in kültür politikaları ile paralel eserler üretir. Kentlileşme çizgisinde gelişen modern hayatı, yeni yaşam mekânlarını, yeni imgesiyle Türk kadınını, gelişen sanayi kollarını ve işçi sınıfını betimler. 1930 ve 1960 'ı yılları, kentlileşme olgusu içinde incelediğimiz resimlerinde çalışan işçiler, kadın veya erkekler idealize edilmiş figürlerden oluşur. Yoksulluğun olmadığı, son derece düzgün ve bakımlı giysileri ile çalışanlar mutlu, neşeli bir profil çizerler. 1940'lı yılların Tütün Işsleyen Kadınlar resmindeki kadın çalışanlarının etek ve elbise kombinleri, 1960'lı yıllarda yaptığı Çini Atölyesi resimlerinde yerel kıyafetlere yerini bırakmıştır. Kuşkusuz bunda değişen iktidarın bakış açısının ve sanata yansıyan yerellik temasının etkisi olmalıdır. Sanatçı parklar ve çay bahçesi gibi halka açık kamu alanlarında kadın-erkek birlikte oturup sohbet ederken betimler. Yalnız bu resimlerde figürlerin yüzlerini soluk ve belirsiz yapmayı tercih eder. Kentsel ölçekte meydan ve meydanları birbirine bağlayan köprü gibi kamusal alana vurgu yapan çalışmalar olarak Haydarpaşa Garı ve Galata Köprüsü çalışmaları artan nüfusu, değişen yaşamı, hava kirliliği gibi kentin getirdiği yeni problemleri resmin konusu yapar. Modernleşme de kentlilik kadar önemli olan eğitim vurgusu da Akdik'in Millet Mektebi, Okula Kayıt gibi resimlerinde yer bulur.

Müstakil Ressamlar ve Heykeltıraşlar Birliği sanatçıları ile balıkçılar, vitrinler, berber dükkânları, köy yaşamı Türk resminde konu olmaya başlamıştır. Akdik de dönemin diğer sanatçılarıyla birlikte benzer toplumsal değişimleri resmeder. Sanayileşme, kentlileşme vurgusu 
SDÜ ART-E

Güzel Sanatlar Fakültesi Sanat Dergisi

Haziran'20 Cilt:13 Sayı:25

ISSN 1308-2698

resimlerinde öne çıkan temalar olarak belirir. Devletin kültür politikasına paralel resimler üretir. Resimlerinde toplumun her katmanında yaşanan değişimleri vurgular. Konu olarak kendisini sınırlamaz. Portrelerinde gerçekçi, manzaralarında ise daha çok izlenimci anlayışla çalışır. Toplumsal gerçeklik içindeki betimleri, kompozisyon kurgusunda bütünlük, ışık ve rengin uyumu Akdik resimlerinin üslupsal özellikleri olarak görülür. 1940 ve 1950 'li yıllarda sanatçı dostları ve eşi ile Fransa, İtalya, Suriye, Beyrut, İspanya, İngiltere gibi yurtdışındaki şehirleri gezer; Atina, Amsterdam, New Jersey gibi şehirlerde davetli olarak sergilere katılır. Hat sanatı üzerine konferanslar veren Akdik, sanat hayatı boyunca geleneksel konulardan kopmadan kendini geliştirir, üretim, kent hayatı ve teknolojinin yansımalarını betimlerine aktarmaya devam eder, öyle ki her bir resmi, modernleşme olgusunun belgesel ifadesini veren çalışmalardan oluşur.

\section{Kaynakça}

Aksel, M. (1942). "Üçüncü Devlet Resim ve Heykel Sergisi”, Güzel Sanatlar Dergisi, Sayı 4, s.23.

Altıntaş, O. (1988). Şeref Akdik, Türk Büyükleri Dizini 77, Sayı: 928.1-1674, Ankara: Kültür ve Turizm Bakanlığı Yayınları: 910.

Arıtan, Ö. (2008). "Cumhuriyet Dönemi Mimarlığı Modernleşme ve Cumhuriyetin Kamusal Mekân Modelleri", Mimarlık, Sayı 342, Temmuz-Ağustos, s.49-56.

Ayan, A. (2014). Batı Anlayışına Dönük Türk Resim Sanatı'nda Görünü (Manzara), İstanbul: Mimar Sinan Güzel Sanatlar Üniversitesi Yayınları.

Baltacıoğlu, ì. H. (1937). “Bir İnkılap Ressamı", Yeni Adam Dergisi, Sayı 161, İstanbul, s.10-11.

Berk, M. (2010). (1938- 43) Yurt Gezileri ve Resim Sanatına Yansımaları, Yayımlanmamış Yüksek Lisans Tezi, İstanbul: Mimar Sinan Üniversitesi Sosyal Bilimler Enstitüsü, Resim Anabilim Dalı.

Berk, N. ve Özsezgin, K. (1983), Cumhuriyet Dönemi Türk Resmi, Ankara: İ̧̧ Bankası Kültür Yayınları.

Bozdoğan, S. (2008). Modernizm ve Ulusun Inşası: Erken Cumhuriyet Türkiyesi'nde Mimari Kültür, İstanbul: Metis Yayınları.

Dellaloğlu Dastarlı, E. (2018). Tanzimat'tan Cumhuriyet'e Türk Resminde Modernleşme: Imgeler ve Batılı Kimlik, Yayımlanmamış Doktora Tezi, İstanbul: İstanbul Üniversitesi Sosyal Bilimler Enstitüsü, Sanat Tarihi Anabilim Dalı. 
SDÜ ART-E

Güzel Sanatlar Fakültesi Sanat Dergisi

Haziran'20 Cilt:13 Sayı:25

ISSN 1308-2698

Elibal, G. (1974). Şeref Akdik, Hayatı, Sanatı, Eserleri, İstanbul: Düzen: Ar Ajans Resim.

Giray, K. (1995). "Yurdu Gezen Türk Ressamları-1/1939-1944 Yurt Sergileri", Türkiye'de Sanat Plastik Sanatlar Dergisi, Mart/Nisan, İstanbul, Sayı 18, s.34-45.

Giray, K. (1997). Müstakil Ressamlar ve Heykeltraşlar Birliği, İstanbul: Akbank Kültür ve Sanat Kitapları: 64.

Giray, K. (2004). Cumhuriyet'in Ilk Ressamları, İstanbul: Türkiye İş Bankası Kültür Yayınları.

Gören, A. K. (2003a). "Cumhuriyet Ruhunun Temsilcisi: Şeref Akdik (1899-1972)", Antik\&Dekor, İstanbul, Sayı 76, s.124-129.

Gören, A. K. (2003b). "Müstakillerin Bir Müstakili Şeref Akdik", Artist Sanat Dergisi, Sayı 10, s.26-31.

İleri C. (ed.), (2007). Modern Deneyimler, 2007-2008 Sürekli Sergi, İstanbul: İstanbul Modern Sanat Vakfı Yayınları.

İskender, K. (1996). “Cumhuriyet'in İlk Yıllarındaki Türk Resmi ve Siyaset iliş̧kileri”, Türkiye'de Sanat Plastik Sanatlar Dergisi, Mart/Nisan, İstanbul, Sayı 23, s.42-45.

Okkalı, i. C. (2014). Türk Resminde iç Mekân Resimleri (1880-1950'li Yıllar), Yayımlanmamış Doktora Tezi, İstanbul: İstanbul Üniversitesi Sosyal Bilimler Enstitüsü, Sanat Tarihi Anabilim Dalı.

Okkalı, i. C. (2017). Kıyafetlerin ve Mekânların İzinde: Şeref Akdik'in Resimlerinde Moda Ve Mekân Çözümlemesi, Art-Sanat, İstanbul, Sayı 8, s.357-376.

Öndin, N. (2003). Cumhuriyet'in Kültür Politikası ve Sanat (1923-1950), İstanbul: İnsancıl Yayınları.

Özden, Ş. (1945). Ressamlar Konuşuyor II, Yeni Sanat, Birincikanun Aralık, Sayı 25, s.8-9.

Tansuğ, S. (1986). Çağdaş Türk Sanatı, İstanbul: Remzi Kitabevi.

Tanyeli, U. (ed.). (1998). Üç Kuşak Cumhuriyet, İstanbul: Tarih Vakfı Yayınları.

Tekeli, i. (1998). “Atatürk Türkiyesinde Kentsel Gelişme ve Kent Planlaması”, Arredamento Mimarlık, Sayı 10, s.61-63.

Ülker, T., Kazancı, Ş., Yılmaz, N., Doğru, E. (2014). Ressam Şeref Akdik Hayatı-Sanatı-Eserleri, Gümüşhane: T.C. Gümüşhane Valiliği Yayınları:16. 
Yaman, Z. Y. (2012). Ankara Resim ve Heykel Müzesi, Ankara: T.C. Kültür ve Turizm Bakanlığı Yayınları Sanat Eserleri Dizisi:486.

Yaman, Z. Y. (1996). "Modernizmin Siyasal/ideolojik Söylemi Olarak Resimde Köylü/Çiftçi İzleği”, Türkiye'de Sanat, İstanbul: Sayı 22, Ocak-Şubat, s.29-37.

Yücel, T. F. (2015). Cumhuriyet Türkiyesi'nin Sanayileşme Öyküsü, Ankara: TTGV.

\section{İnternet Kaynakları}

(1998). http://www.millireasuranssanatgalerisi.com/sergiler/-cumhuriyetin-romansiyurt-gezileri-1938-1943, Erişim tarihi: 06.03.2020.

\section{Görsel Kaynaklar}

Görsel 1. Akdik, "Tütün İşleyen Kadınlar", yaklaşık 1940, Tuval Üzeri Yağlıboya, 55x86 cm, İstanbul Modern Sanat Müzesi. İleri C.(ed.), (2007). Modern Deneyimler, 2007-2008 Sürekli Sergi, İstanbul Modern Sanat Vakfı Yayınları, s.127.

Görsel 2. Akdik, "Metalurji Atölyesi”, 1945, Tuval Üzeri Yağlıboya, $54 \times 65$ cm, İstanbul Modern Sanat Müzesi. İleri C. (ed.), (2007). Modern Deneyimler, 2007-2008 Sürekli Sergi, İstanbul Modern Sanat Vakfı Yayınları, s.126.

Görsel 3. Akdik, "Eskişehir Cer Atölyesi", 1946, Mukavva Üzeri Yağlıboya, 55x65cm, Akbank Koleksiyonu, http://www.rportakal.com/Article.aspx?PagelD=173\&Artld=2000, Erişim tarihi: 06.03.2020.

Görsel 4. Akdik, "Sivas Cer Atölyesi", 1946, Tuval Üzeri Yağlıboya, 55x65cm, Akbank Koleksiyonu. Gören A. K., (1998). 50. Yılında Akbank Resim Koleksiyonu, Akbank Kültür ve Sanat Kitapları: 66, İstanbul, s.79.

Görsel 5. Akdik, "Haydarpaşa Garı”, 1955, Tuval Üzeri Yağlıboya. Ülker, T., Kazancı, Ş. Yılmaz, N., Doğru, E. (2014). Ressam Şeref Akdik Hayatı-Sanatı-Eserleri, Gümüşhane: T.C. Gümüşhane Valiliği Yayınları:16, s.76.

Görsel 6. Akdik, "Galata Köprüsü", 1961, Tuval Üzeri Yağlıboya, 51 x 61 cm, Özel Koleksiyon. http://www.artnet.com/artists/seref-akdik/galata-k\%C3\%B6pr\%C3\%BCs\%C3\%BCpbMPPpNJV QWYq3toUTJyRw2, Erişim tarihi: 06.03.2020.

Görsel 7. Akdik, "Moda Çay Bahçesi”, 1945, Tuval Üzeri Yağlıboya, 38x47cm. http://www.ozbilenlermuzayede.com/muzayedeler-detay.aspx?ID=10\&SanatcilD=175, Erişim tarihi: 06.03.2020. 
SDÜ ART-E

Güzel Sanatlar Fakültesi Sanat Dergisi

Haziran'20 Cilt:13 Sayı:25

ISSN 1308-2698

Görsel 8. Akdik, "Çay Bahçesi", 1961, Tuval-Sunta Üzeri Yağlıboya, $27 \times 34$ cm. http://www.artnet.com/artists/seref-akdik/\%C3\%A7ay-bah\%C3\%A7esiHOiOMEZOBmF8ewGiD Or-Yg2, Erişim tarihi: 06.03.2020.

Görsel 9. Akdik, "Moda Çay Bahçesi", 1952, Yağlıboya. https://www.alifart.com/moda-caybahcesi_85654/,Erişim tarihi: 06.03.2020.

Görsel 10. Akdik, "Çini Yapanlar", 1956, Duralit Üzeri Yağlıboya, 115 x 88,5 cm, TCMB

Koleksiyonu. http://www.turkishpaintings.com/index.php?p=37\&I=1\&modPainters_ artist DetaillD=326, Erişim tarihi: 30.02.2020.

Görsel 11. Akdik, "Çini Atölyesi", 1955, Tuval Üzeri Yağlıboya, 60x71 cm. http://www.artnet.com/artists/seref-akdik/\%C3\%A7ini-at\%C3\%B6lyesi-CTfdB3PFn1_myhdh8 MSxQ2, Erişim tarihi: 03.03.2020.

Görsel 12. Akdik, "Çinici Kızlar", 1955, Tuval Üzeri Yağlıboya, 56x66cm. Elibal, G. (1974). Şeref Akdik, Hayatı, Sanatı, Eserleri, İstanbul: Düzen: Ar Ajans Resim, s.123.

Görsel 13. Akdik, "Okuma Yazma Kursu/Millet Mektebi”, 1933, Tuval Üzerine Yağlıboya, 180x150 cm, MSGSÜ-iRHM. Ülker, T., Kazancı, Ş. Yılmaz, N., Doğru, E. (2014). Ressam Şeref Akdik Hayatı-Sanatı-Eserleri, Gümüşhane: T.C. Gümüşhane Valiliği Yayınları:16, s.95. 